\title{
РЕАКТУАЛИЗАЦИЯ ТЕКСТОВ РУССКОЙ РОК-ПОЭЗИИ В ПЕРЕВОДЕ НА БЕЛОРУССКИЙ ЯЗЫК
}

DOI: http://dx.doi.org/10.12775/RP.2019.016

Zarys treści: W niniejszym artykule poruszono zagadnienie przekładu poezji rockowej z języka rosyjskiego na język białoruski, ukazano główne strategie tłumaczeniowe wybranych utworów z uwzględnieniem ich gatunkowej przynależności. Bazując na Antologii przekładów rosyjskiej poezji rockowej, zwrócono uwagę na konceptualne, semantyczne i gramatyczne modele przekładu. Przeanalizowano formy reaktualizacji tekstu, dostosowujące go do współczesnego odbiorcy, a ponadto rozważono problem zachowania w przekładzie wizerunku bohatera lirycznego oraz symboliczno-społecznego charakteru utworów.

Słowa kluczowe: poezja rockowa, współczesna poezja, przekład konceptualny, lingwokulturologia, kontrkultura

Dок-поэзия в постсоветском пространстве остается недостаточно
изученным жанром. Тексты русского андеграунда оказали заметное влияние на формирование постсоветского культурного кода, актуализация которого происходит снова и снова. Примером такой реактуализации является белорусская Антологии переводов российской рок-поэзии (Анталогія перакладу расійскай рок-паэзіi) ${ }^{1}$, опубликованная в журнале «Дзеяслоў» в 2014 г. Русский рок синтетическое и синкретичное явление, возникшее в 1960-е - 1970-е гг. ХХ в. Его главная особенность - текстоцентричность, что позволяет рассматривать рок-поэзию в методологии и контексте литературы

\footnotetext{
1 Здесь и далее перевод иностранных цитат мой - М.Л.
} 
(Gavrikov 2011: 19-28). «Русский рок» - устойчивая номинация, противопоставленная интернациональной (советской) идеологии (Afanas'ev 2016: 159-167). Русскость рок-поэзии не националистическая, скорее это способ сфокусироваться на индивидуальном самосознании, противопоставленном коллективной этике общественного одобрения.

Перевод русской рок-поэзии на белорусский язык - непростая задача. Во-первых, процесс осложняется спецификой литературного перевода между близкородственными языками, что требует особенного внимания к семантическому полю. Во-вторых, перед переводчиками стояла задача не только перевести стихотворение, но и сохранить ритмическую организацию текста, чтобы песня могла прозвучать на белорусском языке не хуже, чем на языке оригинала, поскольку несмотря на свою текстоцентричность, русский рок - это «три его головы [...] собственно рок-музыка, рок-поэзия и рок-театр [...] отрубленная голова дракона нежизнеспособна» (Smirnov 1991: 5). В-третьих, проблема перевода устойчивых образов, характерных для поэзии андеграунда в целом.

Рок-поэзия с одной стороны является интернациональным явлением, она опирается на западные музыкальные формы и сохраняет определенное единство протестного дискурса. В то же время рок-поэзия исключительно национальна, это “ «,живой” жанр, ориентированный на максимально острое перевыражение наиболее актуальных для представителей своей аудитории реалий с их критической оценкой на основе системы ценностей данной аудитории» (Dostaj 1996: 72). Для рок-поэзии в принципе характерна тесная связь с национальной поэтической традицией (Tera 2002: 146-157), которую в переводах необходимо было сохранить. Общность советского прошлого отчасти упростила задачу белорусских переводчиков, однако сделала более острой проблему переложения национального культурного кода и сохранения своеобразия лирического героя рок-поэзии. Как пишет об этом Наталья Владимировна Ройтберг,

в поэтике рока лирическое «я» максимально приближено к эмпирической личности и биографическому «я» и интерпретируется как двуединство «я» и «другого», автора-творца и героя [...] рок-произведение как жанр «поющегося слова» тяготеет к субъектному синкретизму, для которого характерны единство автора и героя (Rojtberg 2011: 10).

Такая специфика детерминирует смену дискурса переводного текста: единство автора и лирического героя меняется, а стало быть про- 
звучавшие прежде слова наполняются новым содержанием, получают актуализацию в современном контексте.

Эпиграфом к белорусской Антологии переводов российской рок-поэзии послужили строки из стихотворения Бориса Гребенщикова Пабло, которые приводятся на русском языке:

Случилось так, что наша совесть и честь

Была записана у нас на кассетах;

Кто-то принес новой музыки -

И нам больше нечего стало стирать... (Ivashchanka 2014: 199)

Журнал «Дзеяслов» издается на белорусском языке, приведенную в эпиграфе цитату без перевода стоит рассматривать как дань уважения оригиналу.

В рок-поэзии традиционно поднимались вопросы, которые игнорировались в более официальных сферах. Это голос протеста, утверждение ценности индивидуального в противовес коллективному (Pilyute 2011: 40-46). Антология предваряется статьей сотрудника журнала и переводчика некоторых помещенных в ней стихотворений к.ф.н. Анатолия Иващенко, который отметил, что «русский рок - мостик между поколениями. Способ взаимопонимания» (Ivashchanka 2014: 199). Действительно, это общий код, вобравший в себя систему идеалов и моделей протестного дискурса для нескольких поколений в постсоветских странах.

В Антологию вошли стихи 11 поэтов, чье творчество стало признанной классикой жанра: Андрей Макаревич (род. 1953), Борис Гребенщиков (БГ) (род. 1953), Анри Волохонский (1936-2017), Алексей Хвостенко (1940-2004), Виктор Цой (1962-1990), Александр Башлачев (1960-1988), Янка Дягилева (1966-1991), Егор Летов (1964-2008), Умка (Анна Герасимова) (род. 1961), Эдмунд Шклярский (род 1955), Юрий Шевчук (род. 1957). Это легенды русского рока и рок-поэзии, «за каждым из этих имен - свой символ, своя веха (а то и эпоха)» (Ivashchanka 2014: 199). В работе над проектом приняли участие 13 человек: Юрий Нестеренко (Юры Несцярэнка), Федор Живалевский (Фёдар Жывалеўскі), Мария Мартысевич (Марыя Мартысевіч), Алексей Чернявский (Аляксей Чарняўскі), Максим Щур (Макс Шчур), Владимир Дриндрожик (Уладзімір Дрындрожык), Анатолий Иващенко (Анатоль Івашчанка), Роман Ярош (Раман Яраш), Артем Ситников (Арцём Сітнікаў), Сергей Балахонов (Сяргей Балахонаў), Андрей Хаданович (Андрэй Хадановіч), 
Олег Жлутка (Алег Жлутка), Ольга Гронская (Вольга Гронская). Все переводчики известны в Беларуси как музыканты или литераторы.

В интервью, посвященном переводу песни В. Цоя «Перемен» у А. Иващенко спросили о смысле переводов российской лирики, ведь проблема языкового барьера между русскими и белорусами отсутствует. Он ответил: «почему бы иногда в переводе не сказать больше, чем в оригинале?» (Odinets 2011). Больше или нет, но, во всяком случае, иначе. Так, в переводе А. Ситникова («Ракенрол памёр») (Ivashchanka 2014: 214) песни Б. Гребенщикова «Рок-н-ролл мертв» (Grebenshhikov 2013: 146) (1982 г.) происходит перенос действия в современность.

Необходимо отметить, что для своей эпохи этот текст является исключительно знаковым. Артемий Троицкий полагает, что многие назвали бы его гимном советского рока (Troitskij 1991: 103). Перевод выполнен близко к тексту, однако добавление в переводе аллюзий на современные события изменяет культурный код. Текст семантически связывается с событиями в Беларуси 2014 года: строки «Мы встретимся снова, мы скажем «Привет», -/ В этом есть что-то не то» переведены как «Мы стрэнемся зноўку, мы скажам: жыве!/ У гэтым ёсць нешта не тое...» (Мы встретимся снова, мы скажем «жыве!»/ В этом есть что-то не то). «Жыве» (Жыве Беларусь!) - девиз белорусского национального возрождения, появившийся в начале $\mathrm{XX}$ века и не утративший сегодня своей актуальности. Таким образом, «Мы встретимся снова, мы скажем «жыве!»/ В этом есть что-то не то» дополняет текст семантикой современных социокультурных противоречий. Позднее, при исполнении песни А. Ситников заострил этот пласт, изменив строку «У гэтым ёсць нешта не тое...» на «ў гэтым ёсць что-то не так». Хеш-тэг «\#что-то не так» стал вирусным в 2014 году, когда в Минске на съемках фильма о политических протестах в Беларуси актерам массовки запретили скандировать «жыве», потребовав заменить известный слоган нейтральным «что-то не так».

Другим примером реактуализации социально-политического контекста является перевод А. Иващенко стихотворения В. Цоя «Перемен» (Tsoj 2007: 202) (1986 г.) «Перамен!» (Ivashchanka 2014: 218-219). В оригинальном тексте «Красное солнце сгорает дотла/ День догорает с ним», в переводе цвет солнца изменяется на черный: «Чорнае сонца згарае датла,/ дзень дагарае з ім». Эта замена актуализирует политическое значение цвета, «черное солнце» является символом неонацизма, в то время как красный цвет ассоциируется с коммунистической идеологией. Это символическое значение цвета не играет значительной роли 
для понимания оригинального текста, однако в переводе А. Иващенко внимание читателя акцентируется именно на нем. Подобную модель переосмысления оригинального текста можно видеть также в переводе С. Балахонова стихотворения В. Цоя «Кукушка» (Тsoj 2007: 361) (1990 г.) (Зязюля) (Ivashchanka 2014: 217), где пассионарный призыв заменен философским вопросом:

\begin{tabular}{|l|l|l|}
\hline \multicolumn{1}{|c|}{ Оригинал } & \multicolumn{1}{|c|}{ Подстрочник } & \multicolumn{1}{c|}{ Перевод } \\
\hline Солнце моё, взгляни на & Солнце мое - глаз не & Сонца маё - вачэй не \\
меня & скрывай, & хавай, \\
Моя ладонь превратилась & Посмотри, я сжал ладонь & Зірні, я сціснуў далонь \\
в кулак & в кулак, & у кулак, \\
И если есть порох, дай & И дав мне порох, совет & І даўшы мне порах, рады \\
огня! & дай, & дай, \\
Вот так! & Что и как... & Што й як... \\
\hline
\end{tabular}

Подобное переложение традиционно для белорусской литературы. Как пишет об этом Людмила Дмитриевна Синькова, «принципиальный алгоритм развития белорусской литературы подразумевает отказ от идей пусть собственных, но эстетически устаревших; отказ от тех своих традиций, которые прерывались-переиначивались во время, когда наши земли и население находились в титульно и идеологически небелорусских государствах - в пользу более новых, современных новым авторам инокультурных идей, которые всякий раз отечественными создателями осваиваются - и развиваются уже как национальные» (Sin'kova 2013: 11). Не менее ярко этот алгоритм проявляется при переводе различных аллюзий.

В переводе О. Гронской стихотворения Ю. Шевчука «Актриса весна» (Shevchuk 2000: 21) (1987 г.) «Акторка вясна» (Ivashchanka 2014: 229-230) личная вредность заменяется объективной проблемой благодаря введению экотекста:

\begin{tabular}{|l|l|l|}
\hline \multicolumn{1}{|c|}{ Оригинал } & \multicolumn{1}{|c|}{ Подстрочник } & \multicolumn{1}{|c|}{ Перевод } \\
\hline $\begin{array}{l}\text { Солнце-генсек мусолит } \\
\text { лорнет в императорской } \\
\text { ложе, }\end{array}$ & Солнце-генсек с лорнетом & Сонца-генсек з ларнетам \\
$\begin{array}{l}\text { Мрачно ворчит } \\
\text { о расшатанных нервах, } \\
\text { что греть не резон }\end{array}$ & Жалуется на расшатанные & важдаецца уц царскае ложы, \\
нервы и озоновые дыры & нервы й дзіравы азоністаныя \\
& & \\
\hline
\end{tabular}

В переводе Р. Яроша стихотворения Б. Гребенщикова «Не могу оторвать глаз от тебя» (Grebenshhikov 2013: 215) (2005 г.) «Мне не адвесці 
вачэй ад цябе» (Ivashchanka 2014: 213-214) характерный для художественно-эстетического пространства русского рока северный текст заменяется синонимичным образом. В традиции русской рок-поэзии одна из наиболее распространенных трактовок северного текста предполагает его осмысление как «идеальное инобытие мира, в котором каждый автор (...) независимо от мировоззренческих установок ожидает найти воплощение своих идеалов» (Markelova 2014: 299). Это идеализированное пространство свободы и безопасности. Р. Ярош строки «Я родился на севере/ Чтобы дольше оставался цел» переводит северный текст знаком белорусской культуры: «Я нарадзіўся зімой, каб пабачыць сонца вясны» (Я родился зимой, чтобы увидеть солнце весны). В данном случае замена не искажает смысл, но адаптирует его к белорусским реалиям: аграрно-фольклорный текст в белорусской культуре семантически тождественен северному тексту русского рока.

Существует и другое, общекультурное, значение северного текста. Оно связанно со смертью и стагнацией. В этом случае переводчики сохраняют оригинальное слово. Так, в переводе М. Мартысевич стихотворения А. Башлачева «Осень» (Bashlachev 2010: 175) (1984 г.) «Восень» (Ivashchanka 2014: 223-224) использовано слово «поўнач» (север):

\begin{tabular}{|l|l|l|}
\hline \multicolumn{1}{|c|}{ Оригинал } & \multicolumn{1}{|c|}{ Подстрочник } & \multicolumn{1}{c|}{ Перевод } \\
\hline Сны из сукна. & Глаз окна. & Вока вакна. \\
Под суровой шинелью & Под свитком сукна & Пад сувоем сукна \\
спит Северная страна. & Спит Север мой & Спіць Поўнач мая \\
Но где ты, весна? & в трясине. & ў дрыгве. \\
Чем ты сейчас больна? & Да где ты, весна? & Ды дзе ты, вясна? \\
& Что в твоей голове? & Што ў тваёй галаве? \\
\hline
\end{tabular}

Север в оригинальном тексте употребляется в одном из мифологических значений, характерных в первую очередь для рок-поэзии 1980-х. Это север, ассоциирующийся с вечной мерзлотой. В белорусском тексте данный образ передан метафорой болота, пространства столь же многогранно мифологизированного в белорусской культуре, как северный текст в русской. Обоснованной представляется замена «шинели» болеет нейтральным словом «сукно»: милитаристская мифология в целом несвойственна белорусской культуре, военная тема в национальной литературе осмысляется преимущественно в контексте Второй мировой войны и в данном случае введение солдатского образа привнесло бы избыточные коннотации. При этом основная философская проблематика текста в переводе сохранена. 
Иначе в стихотворении Янки Дягилевой «Крестом и нулем» (Letov, Dyagileva, Ryabinov 1994: 112) (1989 г.) «Крыжом і нулём» (Ivashchanka 2014: 225), где в оригинальном тексте север - маркер холода и запустения. В переводе О. Жлутки использовано слово «сіверны», имеющее погодные коннотации: северный ветер, холодная погода. Белорусский вариант «крыжом і нулём запячатаны сіверны дзень» точно передает эпитет русского текста: «Крестом и нулем запечатанный северный день».

Нередки случаи включения в перевод различных маркеров белорусской культуры, как в переложении С. Балахонова стихотворения А. Волхонского «Город золотой» (Volokhonskij 1983: 156) (1972 г.) «Златгорад» (Ivashchanka 2014: 215). Под этим названием стихотворение стало известной песней, однако оригинальное название текста - «Рай». С. Балахонов в подстрочной ссылке приводит характерную для рок-поэзии историю «текстологии заблуждений» (Nikitina 2014: 23-35). Из-за ошибки полностью изменилось восприятие оригинального текста, где действие происходит не «под небом голубым», а «над» ним. В русском тексте город абстрактно-символический, особенно если учитывать, что у автора речь идет о рае или о Небесном Иерусалиме. В белорусском переводе, благодаря введению маркера национальной культуры, конкретизируется место действия. Оно переносится в Северный Иерусалим Вильнюс.

\begin{tabular}{|l|l|}
\hline \multicolumn{1}{|c|}{ Оригинал } & \multicolumn{1}{|c|}{ Перевод } \\
\hline Под небом голубым есть город золотой & Дзе неба найсіней, \\
С прозрачными воротами и ясною & Пад ім злат-горад ёсць \\
звездой & 3 празрыстай вострай брамаю \\
& І зорнай яскрынёй. \\
\hline
\end{tabular}

«Вострая брама» - виленские ворота, над которыми выстроена часовня с иконой Божьей Матери Остробрамской - одной из важнейших христианских святынь Литвы и Беларуси, почитаемая как католиками, так и православными.

Подобное маркирование пространства и актуализация в переводных текстах категорий национальной культуры встречается также в переводах А. Иващенко. Например, в переводе сатирического стихотворения А. Башлачева «Подвиг разведчика» (Bashlachev 2010: 110) (1984 г.) «Подзвіг выведніка» (Ivashchanka 2014: 219-221), где строки «В «Труде» сенсационная заметка/ О том, что до сих пор шумит тайга» восприни- 
маются совершенно иначе, когда вместо «Труда» в текст вводится название белорусской газеты - «Ніва» (сокращенное название сельской общественно-политической газеты «Белорусская Нива», издается с 1921 г.). Образ тайги перестает быть нейтральным, возникает ассоциация со сталинскими репрессиями.

Подобное смещение географии текста изменяет также восприятие переведенного практически дословно сюжета о политических событиях в социалистической Польше. В стихотворении описана забастовка независимого профсоюза «Солидарность» в 1980 - 1981 гг.: «Из братских стран мне сообщает пресса: / Поляки оправляются от стресса. / Прижат к ногтю вредитель Лех Валенса, / Мечтавший всю Варшаву отравить». Поскольку действие переводного текста происходит гораздо ближе, чем действие оригинального - оно воспринимается более конкретно.

Благодаря замене топонимики изменяется смысл и другой строфы, где А. Башлачев сатирически обыгрывает патриотический миф. Первые строки переводчик оставляет без изменений: «Да, вовремя я вышел из запоя.../ Не отдадим родимой Костромы! / Любимый город может спать спокойно/ И мирно зеленеть среди зимы». Далее, в строках «Пройду, как рысь, от Альп и до Онеги/ Тропою партизанских автострад. / Все под откос - трамваи и телеги./ Не забывайте, падлы, Сталинград!» река Онега, текущая на северо-западе России в Архангельской области, заменяется на реку Березу Гродненской области. Образ партизан в оригинальном тексте абстрактен. Архангельская область не была под немецко-фашистской оккупацией, партизанское движение для описанного региона является частью патриотического мифа. На Гродненщине, которая с 1941 по 1944 гг. находилась под немецко-фашистской оккупацией, восприятие образа партизан совсем другое. В переводе подчеркивается, что в тексте сатирически изображается именно советско-патриотический миф. Это усиливается сохранением топонима «Кострома», который в других переводах автора заменяется названием белорусского города.

Подобное изменение контекста также можно видеть в переводе текста стихотворения Б. Гребенщикова «Дубровский» (Grebenshhikov 2013: 163) (1992 г.), где А. Иващенко назвал свою версию именем одного из руководителей восстания 1863 г. «Каліноўскі» (Калиновский) (Ivashchanka 2014: 211-212). Несмотря на то, что переводчик называет свой вариант «вольным переводом», он практически не отступает от оригинального текста. Единственные различия касаются имен и географических названий, Кострома заменяется на Белосток, Саратов и Тверь на Вильно и Смоленск: 


\begin{tabular}{|l|l|}
\hline \multicolumn{1}{|c|}{ Оригинал } & \multicolumn{1}{|c|}{ Перевод } \\
\hline Проснись, моя Кострома, не спи, & Прачніся, мой Беласток, \\
Саратов и Тверь, & не спіце, Вільня й Смаленск. \\
Не век же нам мыкать беду и плакать о & Не век жа нам ліха цярпець \\
хлебе, & і плакаць аб хлебе. \\
Дубровский берет ероплан, Дубровский & Кастусь бярэ аэраплан, \\
взлетает наверх, & Кастусь узлтае ўгару \\
И летает над грешной землей, и пишет & і лятае над грэшнай зямлёй, \\
на небе - & і піша па небе: \\
«Не плачь, Маша, я здесь; & «Не плач, Маша, я тут, \\
Не плачь - солнце взойдет; & не плач, сонца узыйдзе, \\
Не прячь от Бога глаза, & скіруй да Бога пагляд, \\
А то как он найдет нас? & а то як Ён нас знойдзе, \\
Небесный град Иерусалим & нябесны Ерусалім \\
Горит сквозь холод и лед & гарыць праз холад і лёд, \\
И вот он стоит вокруг нас, & і вось ён стаіць вакол нас \\
И ждет нас, и ждет нас...» & й чакае, чакае». \\
\hline
\end{tabular}

Владимир Дубровский - литературный персонаж одноименного романа А.С. Пушкина, Маша - его возлюбленная, Кастусь Калиновский - реальное историческое лицо, как и его невеста Мария. Замена названий городов не случайна: Смоленск, Белосток и Вильно прежде входили в состав Великого княжества Литовского, в разное время эти города вошли в состав России, Польши и Литвы, однако образы данных территорий сохраняются в национальной мифологии Беларуси. Текст обоих стихотворений практически идентичен, но отсылает к принципиально различным контекстам.

Интересно, что такая модель перевода не противоречит оригинальному тексту, поскольку она точно воспроизводит дискурс. Ее использование вполне правомерно. Отметим, что для русской рок-поэзии характерна опора на классическую литературу XIX - первой половины XX вв., опора на исторические события встречается, но нечасто и менее конкретно (Bujnov 2011: 5-9). В белорусской традиции напротив более распространено обращение к историческим реалиям, возникшее в результате распространения идеалов национального возрождения (Rusetskaya 2018: 374-381). Следует отметить, что обращение белорусских рок-поэтов к корпусу текстов классической литературы тоже встречается. Так, один из переводчиков данной антологии, Ф. Живалевский в интервью анонсировал новую программу, в которой «кроме авторских песен, будут композиции на стихи Богдановича, Арсеньевой и Новика-Певуна» (Malinovskij 2011). Подобная актуализация текстов корпуса классики национальной поэзии характерна также для 
русского и польского рока (Bodusz 2009: 410-420; Matveeva 2013: 271-280; Matveeva 2010: 150-154). Наибольшую популярность такая форма рецепции классической поэзии приобретает уже в XXI в.

В переводе Ю. Нестеренко стихотворения А.Макаревича «Я с детства склонен к перемене мест» (Makarevich 2017: 213) (1983 г.) «3 адвечнай прагай перамены месцаў» (Ivashchanka 2014: 201-202) двуединство автора и лирического героя, подчеркнутое постоянным использованием личных местоимений, исчезает:

\begin{tabular}{|l|l|l|}
\hline \multicolumn{1}{|c|}{ Оригинал } & \multicolumn{1}{|c|}{ Подстрочник } & \multicolumn{1}{|c|}{ Перевод } \\
\hline Я с детства склонен & С извечной жаждой & 3 адвечнай прагай \\
к перемене мест: & перемены мест & перамены месцаў \\
Я путаю прощанье & Я путал прощание & Я блытаў развітанне \\
и прощенье, & с прощением, & з дараваннем, \\
Мне дорог в путешествии & Ценным в путешествии & Каштоўным у вандроўцы \\
отъезд, & был отъезд, & быў адезд, \\
Всегда с трудом дается & Всегда с трудом давалось & Заўсёды з цяжкасцю \\
возвращенье - & возвращение. & давалася вяртанне. \\
\hline
\end{tabular}

В первых двух строках зачина исповедальная интонация сменяется повествовательной, настоящее время - прошедшим. Далее в тексте определенно-личные конструкции заменяются безличными. Это создает дистанцию между лирическим героем и исполнителем, между словом и действием, в то время как в оригинале она сведена к минимуму путем постоянного употребления личного местоимения в первом лице единственного числа и перформативных конструкций. Для русской рок-поэзии (и для рок-поэзии в целом) подобные формы в принципе традиционны, а в творчестве А. Макаревича они встречаются особенно часто. В таких текстах «план речи совпадает с планом действия (...) одновременно являясь и речью, и действием» (Konkina 2017: 21), соответственно, замена глагольных форм в данном случае искажает авторский замысел. Однако, поскольку перед переводчиком стояла задача сохранить ритмический рисунок текста, данное решение оправдано.

Подобную замену можно увидеть также в переводе А. Чернявского стихотворения Б. Гребенщикова «С той стороны зеркального стекла» (Grebenshhikov 2013: 76) (1977 г.) «3 другога боку люстранога шкла» (Ivashchanka 2014: 209-210): 


\begin{tabular}{|l|l|l|}
\hline \multicolumn{1}{|c|}{ Оригинал } & \multicolumn{1}{|c|}{ Подстрочник } & \multicolumn{1}{|c|}{ Перевод } \\
\hline $\begin{array}{l}\text { Мне кажется, я узнаю себя } \\
\text { В том мальчике, } \\
\text { читающем стихи; }\end{array}$ & Сдается мне, я был совсем & Здаецца мне, я быў зусім \\
Он стрелки сжал рукой, & Как мальчик тот, что & такі, \\
чтоб не кончалась эта & Як хлопчык той, што \\
ночь, & Он стрелки сжал рукой, & вершы разгарнуў. \\
И кровь течет с руки. & Етобы стрэлі сцяў рукой, каб \\
& истек, & гэты момант не мінуў, \\
& И кровь течет с руки. & I кроў цячэ з рукі. \\
\hline
\end{tabular}

В этом переводе перформативное «я узнаю себя» заменяется формой прошедшего времени «я был таким». Также во второй строке использован глагол «разгарнуць» - раскрыть (книгу), что детерминирует возникновение материального контекста, в то время как оригинальный текст гораздо более метафизичен: мальчик может читать собственные стихи или повторять их по памяти. В переводе опущена первая строфа:

Последний дождь - уже почти не дождь;

Смотри, как просто в нем найти покой.

И если верить в то, что завтра будет новый день,

Тогда совсем легко.

Текст перевода начинается с более или менее конкретного «сегодня» «Ах, только 6 не кончалась эта ночь». В данном случае момент всего лишь текущий, исчезает характерная для русской рок-поэзии цикличность, исчезает философский контекст стихотворения. Замена перформативной конструкции в этом случае отчасти восполняет пропущенную строфу.

На лексическом уровне возникают проблемы перевода философского контекста. Так, название стихотворения Б. Гребенщикова «Неизъяснимо» (Grebenshhikov 2013: 298) (2008 г.) переведено Р. Ярошем как «Без назвы» (Ivashchanka 2014: 212-213) (Без названия). При этом принципиальная неизъяснимость является основой философского плана текста, а само слово «неизъяснимо» звучит в последней строке каждой строфы оригинального текста. Оно переведено как «назвы не мае» (не имеет названия): 


\begin{tabular}{|l|l|l|}
\hline \multicolumn{1}{|c|}{ Оригинал } & \multicolumn{1}{|c|}{ Подстрочник } & \multicolumn{1}{c|}{ Перевод } \\
\hline День еще не прожит & Еще солнце высоко, & Яшчэ сонца высока, \\
Путь еще не начат & Еще дороги ждут. & Яшчэ дарогі чакаюць. \\
Слова в этих книгах & Только эти слова & Толькі гэтыя словы \\
Так мало что значат & Уже не помогают. & Ўжо не дапамагаюць. \\
Я думал, я умный & Я когда-то знал & Я некалі ведаў \\
Ходил играл в прятки & Что говорить, где & Што казаць, дзе схавацца. \\
Я больше не стараюсь & спрятаться. & Я болей не спрабую - \\
Теперь все в порядке & Я больше не пытаюсь - & Навошта старацца? \\
И огонь в глубине & Зачем стараться? & Бо глыбока на дне \\
Горит негасимо & Ведь глубоко на дне & Агонь не згасае. \\
И все неизъяснимо & Огонь не гаснет. & І болей нішто назвы не \\
& И больше ничто названия & мае \\
& не имеет. & \\
\hline
\end{tabular}

В оригинальном тексте речь идет о катафатической теологии, то есть богопознании через проявления Абсолюта в физическом мире: эти частные проявления можно описать, но Бог неизъясним. Поэтому «слова в этих книгах» ничтожны по сравнению с «неизъяснимым» Абсолютом, который они пытаются описать. Насколько тождественным вариантом является использованное переводчиком «Без названия»? Не случайно в тексте приводится сноска с названием оригинального текста. Название - Бог - существует, но Он неизъясним.

Иная ситуация наблюдается в переводе названия стихотворения Е. Летова Ф. Живалевским «Философская песня о пуле» (Letov 1989) (1989 г.) как «Куля-дура» (Ivashchanka 2014: 226-227) (Пуля-дура), таково народное название этой песни. Сочетание «пуля-дура» значимо для смыслового плана текста: первая строка рефрена сохраняется, а вторая изменяется: «Пуля-дура, учи меня жить/ Каземат, научи меня воле», «Пулядура, учи меня жить/ Атеист, научи меня верить», «Пуля-дура, учи меня жить/ Агитатор, учи меня думать». Афоризм А.В. Суворова «пуля - дура, штык - молодец» широко известен как в России, так и в бывших республиках Советского Союза. Перевод названия как «Пуля-дура» заставляет задуматься о конкретных милитаристических процессах современности, в то время как оригинальное название более абстрактно.

Отдельной проблемой перевода текстов рок-поэзии является перевод социолекта. В переложении М. Щура «Гэта канец» песни Умки «Это конец» (Umka 1987) (1987 г.) (Ivashchanka 2014: 227-228) подобные лексические единицы заключены в кавычки: «Ля метро, як мае быць, «аскаў» манеткі» (У метро, как водится, аскал монетки), «На патыліцы «мустанг» цябе не цвеліць» (Ни один мустанг не скачет по затылку). 
Данное решение не кажется удачным: представителям целевой аудитории значение социолектизмов известно, а постороннему наблюдателю они и с кавычками понятнее не становятся. Графическое выделение этих слов выводит их из общего кода, маркирует как чужеродные, что принципиально противоречит оригинальному тексту. «Аскать монетки» в рамках заданного художественного пространства так же естественно, как «собирать объедки» или «ходить в разодранной жилетке». Единственный аргумент в пользу такого решения - это введение в перевод специфического маркера эпохи: «I будзіў цябе ў скверы лягавы, / I ў пад’ездзе - за «ўзровень» баец...» (И будил тебя в сквере легавый/ И в подъезде - за «уровень» боец), в оригинальном тексте: «И будил тебя мент на скамейке/ И на лестничной клетке жилец». Образ бойца за «уровень» отсылает к «образцовому дому» и иным социально одобряемым реалиям советской эпохи, которые основаны на существовании единственной допустимой нормы. Эта номинация оформлена как социолектизм, что деактуализирует текст, закрепляя его в эпохе создания, тогда как в оригинальном тексте такие яркие маркеры времени отсутствуют. Вероятно, в данном случае переводчик пытался уравновесить другую замену: строка «Ты «Войну и Мир» листаешь, как «Мурзилку»» переводится как «Комікс ці «Вайна і мір» - адна чытэльнасць» (Комикс и «Война и мир» - одно чтиво). Комикс обладает коннотацией постсоветского периода. Другим примером изменения временной принадлежности текста является перенос в настоящее, как это было в упомянутом выше переводе А. Иващенко стихотворения В. Цоя «Перемен».

Переводы М. Мартысевич в структуре антологии стоят несколько отдельно: только в них происходит непосредственная трансформация лирического героя. Они удачны как постмодернистная игра, в принципе характерная для творчества поэтессы, это вполне интересное личное переосмысление классических текстов. Необходимо отметить, что М. Мартысевич выбрала для перевода наиболее сложных авторов, тексты которых абсолютно метафоричны и пронизаны многоплановыми аллюзиями. Замена происходит как правило на уровне материального плана, метафизические аспекты переведены максимально близко к тексту. Так, в переводе стихотворения Б. Гребенщикова «Каменный уголь» (Grebenshhikov 2013: 76) (1985 г.) «Каменны вугаль» (Ivashchanka 2014: 206) в строке «В эротических снах молодого дворника» сны становятся «модернистскими». Далее перевод выполнен близко к тексту, однако дискурс принципиально меняется. В стихотворении этого же автора «Стучаться в двери травы» (Grebenshhikov 2013: 93) (1978 г.) «Грукаць 
у дзверы травы» (Ivashchanka 2014: 206-207) первая и третья строфы переводятся практически дословно, а во второй абстрактное заменяется конкретным.

\begin{tabular}{|c|c|c|}
\hline Оригинал & Подстрочник & Перевод \\
\hline $\begin{array}{l}\text { Твоя мать дает мне свой } \\
\text { сладкий чай, } \\
\text { Но отвечает всегда о } \\
\text { другом; } \\
\text { Отец считает свои дела } \\
\text { И считает меня врагом. } \\
\text { И в доме твоем слишком } \\
\text { мало дверей, } \\
\text { И все зеркала кривы; } \\
\text { Так не плачь обо мне, } \\
\text { когда я уйду } \\
\text { Стучаться в двери травы. }\end{array}$ & $\begin{array}{l}\text { Твоя мать, принеся свой } \\
\text { English tеa, } \\
\text { Расскажет о своих коврах. } \\
\text { Твой отец не встанет } \\
\text { подать мне руки } \\
\text { В состоянии холодной } \\
\text { войны. } \\
\text { И в доме твоем слишком } \\
\text { мало дверей, } \\
\text { И вокруг него - рвы. } \\
\text { Так не плачь обо мне, } \\
\text { когда я уйду } \\
\text { Стучать в двери травы. }\end{array}$ & $\begin{array}{l}\text { Твая маці, прынесшы свой } \\
\text { Еnglish tеа, } \\
\text { Апавядзе пра свае } \\
\text { дываны. } \\
\text { Твой бацька не ўстане } \\
\text { падаць мне рукі } \\
\text { У стане халоднай вайны. } \\
\text { I ў доме тваім надта мала } \\
\text { дзвярэй, } \\
\text { І наўкола яго - равы. } \\
\text { Дык не плач пра мяне, } \\
\text { калі я пайду } \\
\text { Грукаць у дзверы травы. }\end{array}$ \\
\hline
\end{tabular}

Замена «сладкого чая» варваризмом «English tea» подчеркивает принадлежность героев к различным пространствам, это противопоставление усиливается заменой оригинального образа не-диалога «отвечает всегда о другом» мещанским образом «ковров», советским знаком материального благополучия, а замена фразы «считает меня врагом» «состоянием холодной войны» маркирует абсолютную непримиримость систем. В завершении строфы кардинально изменяется образ дома: в оригинальном тексте «все зеркала кривы», то есть выдают желаемое за действительное, в переводе - «вокруг него рвы», то есть система обороны. В результате этой замены также исчезает аллюзия на книгу В. Губарева «Королевство кривых зеркал», которая часто встречается в текстах русской рок-поэзии. Лирический герой из философского наблюдателя в этом тексте превращается в яростного противника, что противоречит авторскому замыслу, поскольку, по словам Б. Гребенщикова, текст песни «Двери травы» пришел к нему как продолжение Сильмариллиона Дж. Р. Толкина:

писал я её, находясь в удивительном мире: я сидел утро за утром на лесной поляне в Мюллюпельто, читал недавно вышедший «Сильмариллион» Толкина и всё, что я видел вокруг, принадлежало одновременно двум мирам, потому что карельские леса были прямым продолжением лесов Белерианда (Grebenshhikov 2017). 
Введение М. Мартысевич варваризмов в текст перевода подчеркивает и усиливает противопоставление лирического героя и родителей его возлюбленной и, шире, индивидуальной и коллективной этики.

В переводе стихотворения А. Башлачева «Музыкант» (Bashlachev 2010: 312) (1984 г.) «Музыкант» (Ivashchanka 2014: 222-223) строки «С восемнадцати лет/ Он играл что попало» переведены как «Найстарэйшы між нас, / Ён граў што давядзецца». Старейший из нас - создание общности, в то время как в оригинальном тексте лишь история одного человека. Несколько изменяется образ отношения лирического героя к семье:

\begin{tabular}{|c|c|c|}
\hline Ориг & Подстрочник & Перевод \\
\hline $\begin{array}{l}\text { И из всех новостей } \\
\text { Самой доброй была } \\
\text { Только весть об отъезде } \\
\text { детей. } \\
{[\ldots]} \\
\text { Он мечтал отравить } \\
\text { керосином жену. } \\
\text { Но по ночам он слышал } \\
\text { музыку... }\end{array}$ & $\begin{array}{l}\text { Где лучшей из новостей } \\
\text { Была та, } \\
\text { Что из города уехали } \\
\text { дочки и сын. } \\
{[\ldots]} \\
\text { Он молился, чтобы жену } \\
\text { зло взяло. } \\
\text { Но по ночам он слышал } \\
\text { музыку... }\end{array}$ & $\begin{array}{l}\text { Дзе найлепшай з навін } \\
\text { Была тая, } \\
\text { Што з гораду з'ехалі дочкі } \\
\text { і сын. } \\
\text { [...] } \\
\text { Ён маліўся, каб жонку ліха } \\
\text { ўзяло. } \\
\text { Але начамі ён чуў } \\
\text { музыку... }\end{array}$ \\
\hline
\end{tabular}

В переводе текст сильно смягчается. Абстрактно-номинативное «дети» заменяется конкретным «дочки и сын», а злобное «отравить керосином жену» в переводе становится недовольным ворчанием «чтобы жену зло взяло». Однако в данном случае искажения авторского замысла не происходит: перевод выполнен близко к тексту, с сохранением опорных образов, общих для постсоветского пространства в целом. Например, один из наиболее значимых образов противопоставления профанного и высокого: «Он уходил через черный ход, / Завернув килограмм колбасы / В бумагу для нот» переводится М. Мартысевич дословно.

Таким образом, можно выделить ряд основных моделей перевода рок-поэзии с русского на белорусский язык. Введение знаков национальной культуры при сохранении сюжетно-философской доминанты оригинального текста, что согласуется с традицией переводов рок-поэзии. В этом случае особенный интерес представляет определение переводчиками синонимических контекстов для русской и белорусской культур, ярким примером чего служит замена северного текста русского рока аграрно-обрядовым кодом, характерным для белорусской культу- 
ры. Введение маркеров эпохи, что оправдано лишь при введении маркеров современности. Проблематика рок-поэзии обладает достаточным потенциалом для реактуализации, ограничение значимости текстов лишь социально-историческим контекстом их создания непродуктивно. В переводе текстов рок-поэзии изменение образа лирического героя путем детализации образа либо замены перформативных конструкций продуктивно в тех случаях, когда переводчик хочет усилить дистанцию между исполнителем и лирическим героем.

\section{Литература}

Afanas'ev A.S., 2016, Vzaimodejstvie natsional'nogo i sovetskogo diskursov v tvorchestve Yanki Dyagilevoj, „Russkaya rok-poehziya: tekst i kontekst”, 16, s. 159-167. [Афанасьев А.С., 2016, Взаимодействие национального и советского дискурсов в творчестве Янки Дягилевой, Русская рок-поэзия: текст и контекст, 16, с. 159-167].

Bashlachev A., 2010, Chelovek poyushhij, Moskva. [Башлачев A., 2010, Человек поющий, Москва].

Bodusz M., 2009, Tekst literacki jako tekst rockowy. Utwory romantyczne w obiegu popularnym. Kody kultury: interakcja, transformacja, synergia, Wrocław, s. 410-420.

Bujnov I. A., 2011, Tema istoricheskoj pamyati v rok-poehzii rubezha XX-XXI vekov, „Rhema. Rema”, 4, s. 5-9. [Буйнов И. А., 2011, Тема исторической памяти в рок-поэзии рубежа XX-XXI веков, «Rhema. Рема», 4, с. 5-9].

Dostaj S. A., 1996, Rok-tekst kak sredstvo perevyrazheniya natsional'nogo mentaliteta. Ponimanie kak usmotrenie i postroenie smyslov, Tver', I, s. 71-77. [Достай С. А., 1996, Рок-текст как средство перевыражения национального менталитета. Понимание как усмотрение и построение смыслов, Тверь, I, с. 71-77].

Gavrikov V. A., 2011, Literaturovedenie vs poehtiko-sinteticheskij tekst: v poiskakh metoda, „Russkaya rok-poehziya: tekst i kontekst”, 12, s. 19-28. [Гавриков В. А., 2011, Литературоведение vs поэтико-синтетический текст: в поисках метода, «Русская рок-поэзия: текст и контекст», 12, с. 19-28.]

Grebenshhikov B. B., 2013, Pesni, Moskva. [Гребенщиков Б. Б., 2013, Песни, Москва].

Grebenshhikov B. B., 2017, Dveri travy, Ofitsial'naya stranitsa Borisa 
Grebenshhikova. /wpis: 9.10.2017/, http://aquarium.kroogi.com/ru/ download/3435536-Dveri-Travy.html (dostęp: 5.03.2019). [Гребенщиков Б.Б., 2017, Двери травы, Официальная страница Бориса Гребенщикова. /Публ. 19.10.2017/, http://aquarium.kroogi.com/ru/ download/3435536-Dveri-Travy.html].

Ivashchanka A. (red.), 2014, Antalogiya perakladu rasijskaj rok-paehzii, „Dzeyasloy̆”, 2(69), s. 199-233. [Івашчанка А. (ред.), 2014, Анталогія перакладу расійскай рок-паэзіі, «Дзеяслоў», 2(69), с. 199-233].

Konkina A. Yu., 2017, Performativnaya formula „Ya znayu” v russkoj rokpoehzii 1990-kh gg., „Russkaya rok-poehziya: tekst i kontekst”, 17, s. 19-24. [Конкина А. Ю., 2017, Перформативная формула «Я знаю» в русской рок-поэзии 1990-х гг., «Русская рок-поэзия: текст и контекст», 17, с. 19-24].

Krylova M.N.,2016, Rok-poehziya kaksovremennaya forma sushhestvovaniya poehzii: stilisticheskie osobennosti teksta, „Russkaya rok-poehziya: tekst i kontekst", 16, s. 6-13. [Крылова М. Н., 2016, Рок-поэзия как современная форма существования поэзии: стилистические особенности текста, «Русская рок-поэзия: текст и контекст», 16, с. 6-13].

Letov E., 1989, Filosofskaya pesnya o pule, Grazhdanskaya oborona, Ofitsial'nyj sajt grupy, http://www.gr-oborona.ru/texts/1056964244. html (dostęp: 5.03.2019). [Летов Е., 1989, Философская песня о пуле, Гражданская оборона, Официальный сайт группы, http://www.groborona.ru/texts/1056964244.html].

Letov E., Dyagileva Ya., Ryabinov K., 1994, Russkoe pole ehksperimentov. Egor Letov, Yanka Dyagileva, Konstantin Ryabinov, Moskva. [Летов Е., Дягилева Я., Рябинов К., 1994, Русское поле экспериментов. Егор Летов, Янка Дягилева, Константин Рябинов, Москва].

Makarevich A., 2017, Stikhi. Grafika. Pesni: v 2 t., Moskva. [Макаревич A., 2017, Стихи. Графика. Песни: в 2 т., Москва].

Malinovskij I., 2011, Fedor Zhivalevskij: Khochu delat' literaturnye veshhi, a ne primitivnyj pank-rok, Euroradio.fm, /wpis: 22.08.2011/, https:// euroradio.fm/ru/fedor-zhivalevskiy-hochu-delat-literaturnye-veshchine-primitivnyy-pank-rok (dostęp: 5.03.2019). [Малиновский И., 2011, Федор Живалевский: Хочу делать литературные вещи, а не примитивный панк-рок, Euroradio.fm, /публ.: 22.08.2011/, https:// euroradio.fm/ru/fedor-zhivalevskiy-hochu-delat-literaturnye-veshchine-primitivnyy-pank-rok].

Markelova O. A., 2014, „Severnyj tekst” v sovremennoj otechestvennoj rokpoehzii, „Russkaya rok-poehziya: tekst i kontekst”, 15, s. 292-299. [Map- 
келова О. А., 2014, «Северный текст» в современной отечественной рок-поэзии, «Русская рок-поэзия: текст и контекст», 15, с. 292-299]. Matveeva N. M., 2010, Stikhotvoreniya S. A. Esenina i V. V. Mayakovskogo $v$ sovremennoj pesennoj kul'ture: postroenie tipologii, „Slovo: Sbornik nauchnykh rabot studentov i aspirantov", Tver', Vyp. 8, s. 150-154. [Матвеева Н. М., 2010, Стихотворения С. А. Есенина и В. В. Маяковского в современной песенной культуре: построение типологии, «Слово: Сборник научных работ студентов и аспирантов», Тверь, Вып. 8, c. 150-154].

Matveeva N. M., 2013, Lirika russkikh poehtov XX veka v tvorchestve rok grupp „Nochnye snajpery” i „Surganova i orkestr”, „Russkaya rokpoehziya: tekst i kontekst”, 2013, 14, s. 271-280. [Матвеева Н. М., 2013, Лирика русских поэтов XX века в творчестве рок групп «Ночные снайперы» и «Сурганова и оркестр», «Русская рок-поэзия: текст и контекст», 2013, 14, с. 271-280].

Nikitina O. E., 2014, Pochemu razbityj Gektor odin, ili vvedenie v tekstologiyu zabluzhdenij, „Russkaya rok-poehziya: tekst i kontekst”, 15, s. 23-35. [Никитина О. Э., 2014, Почему разбитый Гектор один, или введение в текстологию заблуждений, «Русская рок-поэзия: текст и контекст», 15, с. 23-35].

Odinets S., 2011, Ivashhenko: „Peremen!” Tsoya ya nachal perevodit’ eshhe do zapreta, Euroradio.fm. /wpis: 20.09.2011/, https://euroradio.fm/ $\mathrm{ru} /$ report/ivashchenko-peremen-tsoya-ya-nachal-perevodit-eshchedo-zapreta-57409 (dostęp: 5.03.2019). [Одинец С., 2011, Иващенко: «Перемен!» Цоя я начал переводить еще до запрета, Euroradio. fm. /публ.: 20.09.2011/, https://euroradio.fm/ru/report/ivashchenkoperemen-tsoya-ya-nachal-perevodit-eshche-do-zapreta-57409].

Pilyute Yu. E., 2011, Idejnye ustanovki i idealy rok-poehzii (na primere tvorchestva russkoyazychnykh i nemetskoyazychnykh avtorov), „Russkaya rok-poehziya: tekst i kontekst”, 12, s. 40-46. [Пилюте Ю.Э., 2011, Идейные установки и идеалы рок-поэзии (на примере творчества русскоязычных и немецкоязычных авторов), «Русская рокпоэзия: текст и контекст», 12, с. 40-46].

Rojtberg N. V., 2011, Chto est' „rok” ili ehkzistentsial'no-tragedijnoe nachalo kak smyslovaya dominanta rok-zhanra, „Russkaya rok-poehziya: tekst i kontekst”, 12, s. 7-13. [Ройтберг Н. В., 2011, Что есть «рок» или экзистенциально-трагедийное начало как смысловая доминанта рокжанра, «Русская рок-поэзия: текст и контекст», 12, с. 7-13].

Rusetskaya N., 2018, „Narodny albom”: belaruskaya i pol'skaya rehtsehptsyya. Belaruska-pol'skiya moy̆nyya, litaraturnyya, gistarychnyya i kul'turnyya 
suvyazi. Da 220-goddzya z dnya naradzhehnnya Adama Mitskevicha: zb. art. pa matehryyalakh mizhnar. navuk. kanf, I. E. Bagdanovich (red.), M. I. Svistunova (red.), Minsk, s. 374-381. [Русецкая H., 2018, «Narodny albom»: беларуская і польская рэцэпцыя. Беларуска-польскія моўныя, літаратурныя, гістарычныя і культурныя сувязі. Да 220-годдзя 3 дня нараджэння Адама Міцкевіча: зб. арт. па матэрыялах міжнар. навук. канф, І. Э. Багдановіч (ред.), М. І. Свістунова (ред.), Мінск, c. 374-381].

Shevchuk Yu. Yu., 2000, Zashhitniki Troi, Sankt-Peterburg. [Шевчук Ю.Ю., 2000, Защитники Трои, Санкт-Петербург].

Smirnov I., 1991, Vtoraya golova rok-drakona. Alternativa. Opyt antologii rokpoehzii, Moskva, s. 5-6. [Смирнов И., 1991, Вторая голова рок-дракона. Альтернатива. Опыт антологии рок-поэзии, Москва, с. 5-6].

Sin'kova L. D., 2013, Pamizh tehkstam i dyskursam: belaruskaya litaratura XX-XXI stst.: gistoryya, kamparatyvistyka i krytyka (lit.-kryt. artykuly, gutarki), Minsk. [Сінькова Л. Д., 2013, Паміж тэкстам і дыскурсам: беларуская літаратура XX-XXI стст.: гісторыя, кампаратывістыка і крытыка (літ.-крыт. артыкулы, гутаркі), Мінск].

Tera M., 2002, Cheshskaya rok-poehziya: ocherk istorii, „Russkaya rokpoehziya: tekst i kontekst", 6, s. 146-157. [Tepa M., 2002, Чешская рокпоэзия: очерк истории, «Русская рок-поэзия: текст и контекст», 6, c. 146-157].

Troitskij A. K., 1991, Rok v Soyuze: 60-e, 70-e, 80-e, Moskva. [Троицкий А. К., 1991, Рок в Союзе: 60-е, 70-е, 80-е, Москва].

Tsoj V. R., 2007, Zvezda po imeni Solntse, Moskva. [Цой В. Р., 2007, Звезда по имени Солнце, Москва].

Umka (A. Gerasimova), 1987, Eto konets, UmkaBase, http://umkabase.org/ song.aspx?id=234 (dostęp: 5.03.2019). [Умка (А. Герасимова), 1987, Это конец, UmkaBase, http://umkabase.org/song.aspx?id=234].

Volokhonskij A., 1983, Stikhotvoreniya, Ann Arbor. [Волохонский A., 1983, Стихотворения, Ann Arbor].

\section{Reconsideration of Russian rock poetry texts relevance regarding their translation into Belarusian \\ Summary}

The paper deals with the problem of translating rock poetry from Russian into Belarusian, identifies the main strategies for translating works with regard to their genres. 
The basic conceptual, semantic and grammatical models of text translation are analysed on the material of the «Belarusian Anthology of Translations of Russian Rock Poetry». Forms of revisions of texts that adjust them to the needs of contemporary audiences were analysed along with the problem of how to retain the image of the lyrical subject as well as symbolic and social nature of poems in translation.

Keywords: rock poetry, modern poetry, conceptual translation, linguistic cultural studies, counterculture 